> Gi rask respons på artikler gjennom artikkelens kommentarfelt på tidsskriftet.no. Respons som er postet innen én måned etter at artikkelen er publisert, vurderes for publisering som Brev til redaktøren i papirutgaven.

Redaksjonen forbeholder seg retten til å foreta redaksjonelle endringer.

Forfattere av vitenskapelige artikler har tilsvarsrett, jf. Vancouver-gruppens regler.

\section{Vi trenger en debatt om politikk, ikke om personer!}

I Rune Slagstads kronikk i Tidsskriftet nr. 12-13/2012 (1) fyres det av i alle retninger - noe treffer, mye bommer. Men debatten om helsepolitikk bør ikke dreie seg primært om hvorvidt direktøren i Helse Sør-Øst og departementsråden i Helse- og omsorgsdepartementet er gode eller dårlige mennesker. Derimot kunne den omhandle viktigere spørsmål, som for eksempel:

Hvor skal grensen gå mellom helsepolitikk og helseadministrasjon? Dette dreier seg både om hvilke beslutninger som skal/bør/ kan ligge på politisk nivå og på hvilket politisk nivå beslutningene skal/bør/kan ligge. Når man eksempelvis i Møre og Romsdal diskuterer plassering av et nytt sykehus, følger skillelinjene kommunegrensene, ikke partigrensene. Hvem skal så ta avgjørelsen og hvem skal levere beslutningsunderlaget? Hvem representerer befolkningen i Møre og Romsdal (og Midt-Norge) best - et direktorat godt plassert i Oslo, et regionalt helseforetak plassert i Midt-Norge eller en fylkesadministrasjon i Molde? Er det mulig for oss å ta denne diskusjonen som en diskusjon av roller, ansvar og myndighet, ikke som en diskusjon av personer?

Hva skal formålet med finansieringssystemet være, og hvordan bør det utformes? Tilgangen på ressurser er begrenset, og det er en målsetting å utnytte disse så godt som mulig. Ut fra dette har man valgt modeller for å «hente inn» (skatt), «fordele ut» (nasjonale og regionale inntektsfordelingsmodeller) og «betale for» (delvis stykkpris). Ingen av modellene er perfekte. Økonomiske modeller kan ha uønskede bivirkninger, og de gjennomføres under betydelig usikkerhet. Klarer vi å ta diskusjonen om forholdet mellom økonomi og helse som en diskusjon av mål og virkemidler uten samtidig å bli fornærmet over at også økonomene har synspunkter?

Hva med forholdet mellom byråkrati, profesjonsinteresser og styringsmodeller? Slagstads kronikk inngår i en tradisjon hvor byråkrater beskrives som ensidig drevet av søken etter makt, konsulentene av ønsket om kortsiktig profitt og «fagfolkene» (herunder selvsagt ikke medregnet økonomene) av pasientenes interesser alene. Slik skapes et bilde av de gode mot de onde, og en diskusjon om løsninger underordnes behovet for å legitimere en elendighetsbeskrivelse som igjen kun er basert på én interessegruppes virkelighetsoppfatning. Vi trenger en diskusjon om interne styringsmodeller som tar inn i seg både kompleksiteten i den virksomheten som utøves og det faktum at alle aktører/profesjoner har egeninteresser knyttet til de beslutningene som tas.

\section{Jon Magnussen}

jon.magnussen@ntnu.no

Jon Magnussen (f. 1959) er professor i helseøkonomi og leder ved Institutt for samfunnsmedisin, Norges teknisk-naturvitenskapelige universitet.

Ingen oppgitte interessekonflikter.

\section{Litteratur}

1. Slagstad R. Helsefeltets strateger. Tidsskr Nor Legeforen 2012; 132: 1479-85.

\section{Magnussens avsporing}

Konflikten mellom sentral styring og institusjonenes autonomi er ikke særegen for Oslo, men tvert imot aktuell i de øvrige helseforetakene og i diskusjonen om museer, utdanningsinstitusjoner m.m. Eksemplet med Molde/Kristiansund er i denne sammenheng egnet til å avspore debatten, ikke til å opplyse den. Her er det et åpenbart motsetningsforhold mellom to mindre institusjoner, ikke mellom institusjoner og sentral styring.

Magnussen gjentar et dogme om motsetning mellom institusjonenes/fagmiljøenes autonomi og de tilgjengelige ressursene. Det er lite som tyder på at dette er tilfellet, tvert imot tyder mye på at for sterk sentral styring svekker trivsel, eierskap og endelig produktivitet, og dermed er dette et omvendt problem. Betydningen av identitet og eierskap synes ofte utelatt fra regnestykkene, til tross for at effekten er velkjent, f.eks. fra hungersnøden etter Lenins jordbrukspolitikk. Det er jo heller ikke slik at sykehusene i Oslo generelt sliter, de private sykehusene i hovedstadsområdet klarer seg utmerket, til tross for at de ikke er velsignet med guddommelig inngripen fra Helse Sør-Øst eller departementet.

Magnussen anfører fagmiljøenes egeninteresser, men unnlater å inkludere seg selv i dette. Slagstad peker på uheldig sammenblanding mellom konsulentvesenet og helseadministratorene og skisserer en dynamikk som ikke tjener til en heldig utvikling av institusjonene. Denne mekanismen er ganske åpenbar, her kan det oppstå gjensidig forsterking $\mathrm{i}$ etablering av systemer og styring som ikke tjener andre interesser enn disse aktørenes. Det er vanskelig å se noen korrigerende faktor i dette, annet enn resultatet i form av fallerende virksomhet under de store institusjonene kontrastert av blomstrende mindre, private sykehus. Dette er allerede overtydelig i Oslo, hvor universitetssykehuset nå forsøker å få de private til å ta over virksomhet innen ulike fagområder.

At fagmiljøene i første rekke forfekter egeninteresser synes Magnussen å ta for gitt. Dette er for så vidt illustrerende for avstanden og en utbredt oppfatning som har vært medvirkende til denne omnipotensen blant enkelte helseadministratorer. Deler av det helseøkonomiske fagfeltet synes ganske umodent og beruset av en forestilling om hva som kan oppnås ved sentral styring.

\section{Christian Grimsgaard \\ cgrimsga@ous-hf.no}

Christian Grimsgaard (f. 1969) er spesialist i ortopedi, med spesialkompetanse innen håndkirurgi. Han er ansatt ved hånd-og mikrokirurgisk seksjon ved Ortopedisk avdeling, Oslo universitetssykehus. Han har fra 2010 vært tillitsvalgt for overlegene ved Klinikk for kirurgi og nevrofag. Ingen oppgitte interessekonflikter.

\section{En ødeleggende prosess}

Jeg takker Rune Slagstad, som i Tidsskriftet nr. 12-13/2012 nøster i hvordan Oslo-sykehusene havnet i den nåværende situasjonen (1). Jon Magnussen mener Slagstad er for personfokusert og vil ha en mer prinsipiell debatt. Jeg opplever ødeleggelsen av Oslo-sykehusene som en ubegripelig realitet og vil gjerne vite hvordan de styrende prosessene faktisk foregikk og foregår. Slagstad får frem hvordan det er en blanding av personligheter og prinsipper som har ledet oss dit vi er.

Slagstad tar faktisk opp mange ikke-personrelaterte faktorer, som for eksempel faktagrunnlaget man bygde fusjonsbeslutningene på. 
Han viser hvordan både departementet og Helse Sør-Øst la til grunn at det kunne spares astronomiske beløp. Så store vurderte man innsparingsmulighetene til å være at sammenslåingen skulle gjennomføres helt uten eksterne omstillingsmidler. Dermed fikk Oslo universitetssykehus ikke engang adgang til å planlegge med underskudd de første årene for å frigjøre interne omstillingsmidler. Slagstad viser også til konsulentselskapenes sentrale rolle i Oslo-prosessen. Gevinsten for pasienter, ansatte og samfunnet har vist seg tvilsom, mens gevinsten for McKinsey sannsynligvis er utvilsom?

Sentrale aktører ønsker i ettertid ikke å diskutere grunnlagene for fusjonsprosessen. Som Slagsstad viser benektet Mari Trommald kjennskap til innsparingsanslagene. Vil hun bli trodd på det, eller dekker hun seg bak begrepet «et konkret resultatmål på ressursbruk»? I Søndagsavisa i NRK P2 1.7. 2012 hevdet statssekretær Robin Kåss at han ikke kjente til at McKinsey var involvert i prosessen. Er Kåss tilfreds med å konstatere at her vet han ikke hva hans eget departement og underliggende foretak har bedrevet? Når sentrale politikere henviser til de nåværende resultater på for eksempel kreftbehandling som bevis på at fusjonsprosessen har lyktes, har de ikke den minste forståelse for at resultater av forskning og utvikling tar langt mer tid enn som så. Resultatene av dette eksperimentet vil vi ikke se før om mange år.

Slagstad fortjener ros for å ha løftet frem fusjonspremisser som beslutningstakerne i etterkant fortrenger og for å påpeke reelle negative effekter der Kåss vil sole seg i positive fenomener som åpenbart skyldes andre forhold enn fusjonen. Da Kåss i samme intervju i Søndagsavisa ble presset på at ikke alt i Oslo universitetssykehus var perfekt, la han alt ansvaret over på den gamle ledelsen. Med ny ledelse ville problemene forsvinne. Han aksepterte altså ikke at problemene har med sviktende forutsetninger eller manglende omstillingsmidler fra departement eller Helse Sør-Øst å gjøre. Kåss avsluttet med å hevde at alle nå slutter opp om sammenslåingen. For oss som arbeider ved Oslo universitetssykehus til daglig er det vanskelig å forstå hvor han henter en slik påstand fra. Hvor mange av dem som eventuelt støtter en sammenslåing gjør det under forutsetning av økonomiske rammer som muliggjør reell effektivisering og kvalitetsheving?

Synspunktene her er mine egne.

\section{Gunnar Birkeland Flugsrud}

gunnar.flugsrud@ioks.uio.no

Gunnar Birkeland Flugsrud (f. 1961) er ph.d. og overlege ved Ortopedisk avdeling, Oslo universitetssykehus, Ullevål.

Ingen oppgitte interessekonflikter.

\section{Litteratur}

1. Slagstad R. Helsefeltets strateger. Tidsskr Nor Legeforen 2012; 132: 1479-85.

\section{Kort replikk til Grimsgaard}

$\mathrm{Ja}$, jeg sporer av. Jeg er mer glad i en debatt som går på prinsipper og løsninger snarere enn på personer, det var hensikten med innlegget.

Nei, jeg hevder ikke at det er en nødvendig motsetning mellom institusjonenes/fagmiljøenes autonomi og tilgjengelige ressurser. Tvert i mot reiser jeg som en problemstilling (uten å ha noe svar) $\mathrm{i}$ hvor stor grad beslutninger kan/skal/bør være (sentralt/desentralt) politiske/administrative/faglige.

Nei, jeg sier ikke at fagmiljøene «i første rekke» forfekter egeninteresser, jeg sier at det er nødvendig å ta med i diskusjonene at også fagmiljøene har egeninteresser. Ordene «i første rekke» endrer innholdet $i$ utsagnet og tillegger meg meninger jeg ikke har.

Jo, eksemplet Molde/Kristiansund er relevant. Det illustrerer at «ikke-faglige» beslutningstakere (f.eks. politikere) ikke nødvendigvis kan basere beslutninger på den input de får fra fagmiljøene. Det reiser igjen spørsmålet om hvordan samfunnet best kan fremskaffe gode premisser for nødvendige beslutninger.
Jon Magnussen

jon.magnussen@ntnu.no

Jon Magnussen (f. 1959) er professor i helseøkonomi og leder ved Institutt for samfunnsmedisin, Norges teknisk-naturvitenskapelige universitet. Ingen oppgitte interessekonflikter.

\section{R. Slagstad svarer:}

Professor i helseøkonomi Jon Magnussen er åpenbart irritert over min artikkel Helsefeltets strateger i Tidsskriftet nr. 12-13/2012 (1). Det er en irritasjon jeg ingenlunde vil frata ham. Han mener jeg burde ha skrevet en annen artikkel og anfører flere momenter til en slik, så som det mest rasjonelle politiske nivå for helsepolitiske beslutninger og formålet med finansieringssystemet og dets utforming. Dette er viktige spørsmål som Magnussen gjerne må skrive flere artikler om, utover dem han allerede har begått. Hva de har med min analyse av fusjonsprosessen ved Oslo universitetssykehus å gjøre, forblir mer uklart.

Min analyse av det maktpolitiske spillet om Oslo universitetssykehus mener han åpenbart å kunne punktere med alminneligheter: Det fyres av «i alle retninger», «noe treffer, mye bommer», dog uten den minste antydning til konkretisering av «alle», «noe» eller «mye». Magnussens eneste konkrete henvisning er at debatten om helsepolitikk ikke primært bør dreie seg om hvorvidt direktøren i Helse Sør-Øst og departementsråden i Helse- og omsorgsdepartementet «er gode eller dårlige mennesker». Det er et synspunkt det er vanskelig ikke å være enig i, og den stråmann som måtte ha hevdet dette, bør melde seg.

De intellektuelle «short-cuts» Magnussen gjør bruk av, ville vært liten grunn til å oppholde seg nærmere ved om det ikke var for at han selv har vært - og er? - en viktig premissleverandør for den offisielle helsepolitikk (jf. bl.a. Magnussen-utvalgets utredning om inntektsfordelingen mellom de regionale helseforetakene) (2). Men det finnes, så lite svart-hvitt det enn måtte høres, flere fenomener i den helsepolitiske verden enn dem som fanges inn av Magnussens økonomiske modeller. Jeg har pekt på noen aktører som mer eller mindre i det skjulte har vært retningsgivende for den helsepolitiske reformismen, ikke minst en lite påaktet styringssymbiose mellom «doldisbryåkrater» og en ekspanderende konsulentbransje med McKinsey i spissen. I dette miljøet er ikke sansen for den tradisjonelle faglige kompetansen den mest påfallende. Det er en observasjon med relevans også utover helsefeltet, men det oppløftende er at på dette feltet møter de nye styringsagentene en langt sterkere faglig forankret motstand enn på andre samfunnsfelter. Det påhviler ikke minst legene et betydelig samfunnsansvar med henblikk på enda tydeligere å artikulere offentlig sin opposisjon.

Kanskje er vi her ved en av grunnene til at konkretisering av strateger er så problematisk for Magnussen? Om kritikk rettes kun mot «systemet» og overser bevegerne for den sosiale konstruksjon som politikk (eller økonomi) er, kan man kanskje fortsette å anta at «politikk ikke (er) personer». Men det bør den ikke dersom konstruktiv reorientering er målet. Vi trenger en debatt om politikk, ikke om personer! er Magnussens overskrift. Hans ansvarsfritakende synspunkt ville i det minste vært mer konsistent om han ikke hadde rettet sin kritikk nettopp mot min person. Det finnes et elementært akademisk begrep for slik selvmotsigende atferd: selvrefererende inkonsistens.

\section{Rune Slagstad}

rune.slagstad@hioa.no

Rune Slagstad (f. 1945) er dr.philos. og professor ved Senter for profesjonsstudier, Høgskolen i Oslo og Akershus.

Ingen oppgitte interessekonflikter.

\section{Litteratur}

1. Slagstad R. Helsefeltets strateger. Tidsskr Nor Legeforen 2012; 132: 1479-85.

2. Norges offentlige utredninger. Fordeling av inntekter mellom regionale helseforetak. NOU 2008: 2. 